\title{
Garments, Signatures, and Ottoman Self-Fashioning in the Imperial Periphery: Moldavian Voyvode Ştefan Tomşa II and Ottomanization in the Early Seventeenth Century
}

\author{
Michat Wasiucionek \\ New Europe College (LuxFaSS) / Nicolae Iorga Institute of History, \\ Bucharest, Romania \\ michal.wasiucionek@eui.eu
}

\begin{abstract}
The paper examines the strategies of self-representation pursued by Moldavian Voyvode Ștefan Tomșa II (r. 1611-1615, 1621-1623). From his ascension to the throne, Tomșa faced accusations of wholesale adoption of Ottoman customs and fashion, and even conversion to Islam. While Romanian scholars have largely dismissed these claims as a product of hostile propaganda, the paper argues that - while remaining an Orthodox Christian - the voyvode deliberately emphasized his affinity to the Ottoman cultural idiom and presented himself to his subjects as a member of the Ottoman ruling class. By examining the nexus between Tomșa's career, material objects he commissioned, and chancery innovations during his reign, the paper looks into the process of Christian Ottomanization in the Danubian principalities of Moldavia and Wallachia.
\end{abstract}

\section{Keywords}

Ottoman Empire - Moldavia - identity - material culture - self-fashioning

\section{Introduction}

The closing months of 1611 saw the principality of Moldavia plunged into chaos upon a contentious change on the throne, as the incumbent voyvode, Constantin Movilă (1607-1611), was dismissed by the Ottomans and replaced 
with the Sublime Porte's new appointee, Ștefan Tomșa II (1611-1615, 1621-1623). Unable to withstand the Ottoman troops and unwilling to give up the throne, Movilă and his partisans fled under Polish-Lithuanian protection and embarked on a frenetic effort to discredit their adversary and rally their allies. In their correspondence with Polish-Lithuanian and Habsburg officials, they alleged that Tomșa's allegiance to the sultan went beyond the realm of politics; rather, the new voyvode had effectively "become a Turk in his manners and attire" and as such posed an unprecedented threat to the principality. ${ }^{1}$ The allegations that Ştefan Tomşa was a "wholly a Turk" clearly caught on: in the following years, Polish and Habsburg officials repeatedly referred to the voyvode's "Turkishness," going so far as to present him as a member of the janissary corps. ${ }^{2}$

However, what constituted Tomșa's alleged "Turkishness"? Throughout the early modern period, "turning Turk" was most commonly employed to describe conversion to Islam, but there is no indication that the Moldavian voyvode ever became a Muslim; on the contrary, he remained a member and benefactor of the Orthodox Church throughout his life. ${ }^{3}$ Having dispelled the possibility of conversion, Romanian scholars have dismissed the allegations as unfounded slander in the tug-of-war, and Tomșa's apparent fondness for "Turkish" garments as a mere pretext for his detractors. ${ }^{4}$ However, what this explanation fails to take into account is that the Moldavian elite had by the early seventeenth century embraced Ottoman-style garments and integrated them into their own material culture. ${ }^{5}$ Somewhat ironically in the context of

1 Documente privitoare la istoria Ardealului, Moldovei și Țării Românești [Documents on the history of Transylvania, Wallachia and Moldavia], vol. 8, ed. Andrei Veress (Bucharest, 1935), 242-243; Documente privitoare la istoria românilor [Documents regarding the history of Romanians], ed. Eudoxiu de Hurmuzaki [hereafter: Hurmuzaki], vol. iv/1 (Bucharest, 1882), 461-463.

2 Ibid., 240-241; Ilie Corfus, Documente privitoare la istoria României culese din arhivele polone. Secolele al XVI-lea și al XVII-lea [Documents regarding the history of Romania, collected from Polish archives. Sixteenth and seventeenth centuries], ed. Vasile Matei (Bucharest, 2001), 185 .

3 For a recent discussion of "turning Turk," see Tobias Graf, The Sultan's Renegades: Christian-European Converts to Islam and the Making of Ottoman Elite, 1575-1610 (Oxford, 2017), 59-6o. For the Balkans, see Sanja Kadrić, "The Islamisation of Ottoman Bosnia: Myths and Matters," in Islamisation: Comparative Perspectives from History, ed. A.C.S. Peacock (Edinburgh, 2017), 277-295.

4 "It is very likely that Tomșa adopted oriental garments and some customs [...] However, this does not mean that he converted to Islam. After all, he resided for some time in Istanbul, and it would not be surprising for him to adopt some local customs," Aurel Iacob, Țara Moldovei în vremea lui Ștefan Tomșa al II-lea [Moldavia in the times of Ștefan Tomșa II] (Brăila, 2010), 65.

5 See Corina Nicolescu, Istoria costumului de curte în Țările Române: secolele XIV-XVII [History of court attire in the Romanian countries, fourteenth to seventeenth centuries] (Bucharest, 
the accusations, a portrait of Ieremia Movilă—father of Tomșa's adversarydressed in an Ottoman hil'at adorns the cover of a recent book addressing the empire's impact on early modern Europe. ${ }^{6}$ In such a sartorial environment, it seems unlikely that Ștefan Tomșa and his "Turkish" garments would have stood out in any significant way. In this context, rather than why the voyvode should don Ottoman-style clothes, the main puzzle is why his choice to do so should be politicized by the local elite with their accusations of his being "wholly a Turk."

As I argue in this paper, while evidently meant to discredit the voyvode, the accusations of Ștefan Tomșa's "Turkishness" contained a kernel of truth. A closer examination of the extant sources demonstrates that the voyvode leaned on rather than shied away from his ties with the Sublime Porte and consciously emphasized them. In so doing, he adopted sultanic models and portrayed himself as a member of the imperial elite. From this point of view, the accusations against Tomșa merely put a negative spin on the self-fashioning that the voyvode employed in dealing with the local elite. In spite of Tomșa's never becoming a Muslim, he fits into the broader spectrum of "turning Turk," which "embodies a very rich set of possibilities, from simply dressing up in a kaftan and turban to actual conversion to Islam and service to the Ottoman court." At the same time, it provides us with a glimpse into the wider phenomenon of Ottomanization among the Christian provincial elites of the empire and the voyvode's role as an agent of the process.

The term "Ottomanization," which I employ in the present study, requires some explanation. I use it to refer to a process of social, political, economic, and cultural entanglement between local elites and imperial officialdom that began in the second half of the sixteenth century. The evolution of imperial governance in this period, characterized by the proliferation of tax-farming and the changing pattern of military recruitment, not only contributed to intensifying interaction between the imperial administration and local notables but also provided the latter with incentives to enter the realm of Ottoman governance, which provided opportunities for profit and upward mobility. ${ }^{8}$ This

1970); Alexandru Alexianu, Mode și veșminte din trecut: cinci secole de istorie costumară românească [Fashions and garments of the past: five centuries of Romanian costume history], vol. 1 (Bucharest, 1971).

6 Nurhan Atasoy and Lâle Uluç, Impressions of Ottoman Culture in Europe, 1453-1699 (Istanbul, 2012).

7 Virginia Aksan, “Who Was an Ottoman? Reflections on 'Wearing Hats' and 'Turning Turk,'” in Barbara Schmidt-Haberkamp (ed.), Europa und die Türkei im 18. Jahrhundert (Bonn, 2011), 306.

8 On this topic, see especially Baki Tezcan, The Second Ottoman Empire: Political and Social Transformation in the Early Modern World (Cambridge, 2010). 
increasing engagement with the imperial structures led to the "gradual political, economic, social and cultural integration of provincial notable families into the Ottoman elite."9 Along with the parallel process of imperial officials' localization, this dual process of gradual merger resulted in the emergence of Ottoman-local elites, who positioned themselves as intermediaries between the local community and the imperial center and pivotal actors within the sphere of governance. This process of inclusion of local notables into the imperial machinery revolved around several points of convergence, most notably grandee households, which acted as economic and political blocs, as well as the main channels of recruitment and acculturation into the Ottoman elite and culture. ${ }^{10}$

Obviously, such a framework does not encompass all the phenomena that students of the empire have identified as signs of Ottomanization. However, it offers considerable advantages. ${ }^{11}$ On the one hand, it provides a comprehensive yet flexible framework for the growing integration between local elites and the imperial center, focusing on social, political, and economic entanglements. Secondly, as students of the Ottoman Balkans are careful to point out, Ottomanization should not be confused with Islamization, which was an often-related but nonetheless distinct process. ${ }^{12}$ In fact, recent scholarship has increasingly shown numerous ways in which non-Muslim elites participated in imperial governance and constructed and performed their "Ottomanness."13 As I shall demonstrate, Ștefan Tomșa II subscribed to this broader phenomenon, and fashioned his image as a Christian member of the Ottoman elite.

While Tomșa's tumultuous reigns in Moldavia garnered the attention of his contemporaries, there are considerable obstacles to reconstructing the voyvode's self-fashioning strategy, mostly due to the character of extant

Ehud Toledano, "The Emergence of Ottoman-Local Elites (1700-190o): A Framework for Research," in Middle Eastern Politics and Ideas: A History from Within eds. Ilan Pappé and Moshe Ma'oz (London, 1997), 154. See also Dina Rizk Khoury, State and Provincial Society in the Ottoman Empire: Mosul, 1540-1834 (Cambridge, 1997); Hülya Canbakal, Society and Politics in an Ottoman Town: Ayntāb in the 17th Century (Leiden, 2006), 6.

10 Carter Vaughn Findley, "Political Culture and Great Households," in The Cambridge History of Turkey, ed. Suraiya Faroqhi, vol. 3 (Cambridge, 2006), 65-80.

11 See Michał Wasiucionek, "Conceptualizing Moldavian Ottomanness: Elite Culture and Ottomanization of the Seventeenth-Century Moldavian Boyars," Medieval and Early Modern Studies for Central and Eastern Europe 8 (2016): 46.

12 See, for instance Evgeni Radushev, "The Spread of Islam in the Ottoman Balkans: Revisiting Bulliet's Method on Religious Conversion," Archiv Orientalni 78 (2010): 368-369.

13 Antonis Anastasopoulos, "Introduction," in Provincial Elites in the Ottoman Empire, ed. Antonis Anastasopoulos (Rethymno, 2005), xvi; Ali Yaycioglu, Partners of the Empire: The Crisis of the Ottoman Order in the Age of Revolutions (Stanford, 2016). 
sources. The correspondence and narrative accounts we have at our disposal originate almost exclusively from quarters hostile to Tomșa. This is particularly the case for Polish-Lithuanian nobles and chroniclers, who unanimously sided with the Movilăs, given the family's close political and familial ties to the Commonwealth. The same lens is adopted in the sole Moldavian chronicle pertaining to this period, the work of Miron Costin, whose family owed their career to the Movilăs' patronage and who was educated in a Jesuit college in the Polish town of Bar. ${ }^{14}$ As a result, they provide us with a biased portrayal of Ștefan Tomșa, curated by his adversaries, rather than the image that the voyvode sought to convey. Most authors focus primarily on the unfolding of the military struggle with the Movilă family rather than on the voyvode himself. On the other hand, visual evidence and garments that can be associated with the voyvode are scant and their character makes it difficult to address his self-fashioning strategy. As a result, while the allegations of "Turkishness" mounted by his adversaries focused primarily on his garments and customs, it is almost impossible to reconstruct the sartorial biography of the voyvode or to identify pieces of clothing in his possession. Instead, in trying to reconstruct Tomșa's self-fashioning strategy and the identity he tried to convey, we should turn to diplomas and privileges issued by the voyvodal chancery. While these documents seemingly provide us with little information on the topic at hand, scavenging for sources regarding Ștefan Tomșa's self-fashioning strategies and reading them against the grain sheds new light on how the voyvode wanted to be seen. As I shall argue, examining the career of the voyvode and the objects and cultural models he embraced allows us to see that Ștefan Tomșa II consciously cast himself as a participant in Ottoman imperial culture. Thus, while never crossing the confessional boundary, he acted as an agent of Ottomanization in Moldavia.

In the pages that follow, I shall bring together three different circuits spanning the imperial center and Moldavia, which, taken together, allow us to recover Ştefan Tomşa II's voice. In the first section, I shall address the voyvode's career, focusing on his embeddedness in the political and social networks of the imperial establishment, which not only paved his way to the Moldavian throne, but also underpinned his claim to "Ottomanness." I shall go on to examine the references to Tomșa's sartorial preferences, and their place within the larger context of his activity. Finally, I shall turn to Tomşa's signature. While generally overlooked by historians, the voyvode's cipher-inspired by Ottoman sultans' tuğras, but adapted to local chancery practices-not only proves that the Moldavian ruler deliberately showcased the Ottoman aspect

14 Miron Costin, Opere [Collected works], ed. Petre P. Panaitescu (Bucharest, 1958). 
of his identity, but also reflected a wider process of Ottomanization that swept through the empire in the seventeenth and eighteenth centuries. Finally, I shall return to the concept of Ottomanization, arguing for both a broader and more actor-centered perspective on the process, as driven by individual agencies and immediate conflicts.

\section{In the Voyvode's Footsteps: Human Mobility and Political Integration}

Prior to ascending the Moldavian throne, Ștefan Tomșa II's career was a complex one, spanning most of the continent. While the paucity of sources makes it difficult to retrace individual steps and even his family connections, there seems to be no doubt that the future voyvode was born in the $155 \mathrm{Os}$, the son of Ștefan Tomșa I, an influential boyar of the mid-sixteenth century. In 1563 , the latter managed to rise to the throne as a leader of a rebellion against the incumbent; however, by March 1564, the failure to secure Ottoman confirmation forced Tomșa I to flee to Poland, where he was subsequently detained and executed at the Sublime Porte's behest. ${ }^{15}$ The family seem to have suffered considerably from these events, losing much of its landed property and political clout within the principality. ${ }^{16}$ It is most likely in the context of the family's impoverishment that young Ştefan (II) chose his career as a soldier of fortune. Starting from the late 1570s, he fought on numerous battlefields, in Polish-Lithuanian, French, and Habsburg service before arriving in Istanbul around 1600 and making his bid for the Moldavian throne. ${ }^{17}$

The future voyvode's early efforts to achieve this goal are impossible to retrace given the dearth of sources; however, there is no doubt that his initial position was relatively weak in comparison with his main rivals. Since 1595 , Moldavia had been ruled by voyvodes of the Movilă family, who had established a powerful coalition within the principality and enjoyed considerable support in Poland-Lithuania. Even in Istanbul, Tomșa's main rival was Ștefan Bogdan, who enjoyed considerable support from the English embassy. ${ }^{18}$ The relative

\footnotetext{
15 Andrzej Dziubiński, Stosunki dyplomatyczne polsko-tureckie w latach 1500-1572 w kontekście międzynarodowym [Polish-Turkish diplomatics relations in the 1500-1572 period in the international context] (Wrocław, 2005), 246.

16 Paweł Piasecki, Kronika Pawła Piaseckiego biskupa przemyślskiego [Chronicle of Paweł Piasecki, the Bishop of Przemyśl], ed. Antoni Chrząszczewski (Cracow, 1870), 251.

17 Iacob, Țara Moldovei, 72.

18 For the most comprehensive account of the events, focusing on Ștefan Bogdan and his ties to the English court, see Laura Coulter, "The Involvement of the English Crown
} 
weakness of Tomşa's alliances at this stage undoubtedly contributed to the debacle of his first attempt to capture the Moldavian throne in $1607 .{ }^{19}$ It seems that although by this point the future voyvode had established some alliances in the imperial capital, they were insufficient to launch a successful bid.

However, within the next four years the situation changed considerably, as Ştefan Tomşa managed to expand his power base and establish an influential web of alliances within the Ottoman establishment, paving his way for his appointment in November 1611. For this purpose, he harnessed his military experience in the Ottoman service, spending some time in eastern Anatolia fighting against the Safavids. ${ }^{20}$ This episode seemingly sparked rumors that Tomșa was a member of the janissary corps, which is unlikely given his adherence to the Orthodox Church. Instead, it is far more likely that he was employed as a sekban mercenary, a category whose employment spiked in the chaos of celali rebellions, growing factionalism, and socio-economic changes throughout the empire. ${ }^{21}$ Given Tomşa's ample military experience, he would have had no difficulty finding employment in this capacity. While the evidence is circumstantial, it seems plausible that his employer was Nasuh Pasha, the largest mercenary employer among Ottoman commanders of this period and future grand vizier. Following his appointment to the grand vizierate, Nasuh Pasha staunchly supported the voyvode and dismissed Polish-Lithuanian demands to replace him with a less contentious candidate. ${ }^{22}$

Nasuh Pasha was not Tomșa's only patron within the Ottoman establishment; among other members of his alliance we find kaymakam Gürcü Mehmed Pasha. According to French reports, this grandee accepted the future voyvode into his household, providing him with accommodation during the latter's stay in Istanbul. ${ }^{23}$ Apart from vertical integration of a client-patron bond, immersion in the household provided opportunities for establishing lateral ties with other officials: in 1622, according to Prince Krzysztof Zbaraski, Polish-Lithuanian ambassador to the Porte, Gürcü Mehmed Pasha called both

and Its Embassy in Constantinople with Pretenders to the Throne of the Principality of Moldavia between the Years 1583 and 1620," (Ph.D. diss., University of London, 1993); see also, Nicolae Iorga, "Pretendenți domnesci în secolul al XVI-lea [Voyvodal pretenders in the sixteenth century]," Analele Academiei Române, Seria II, 19 (1898): 255-259.

19 There is very little information regarding this bid, the only source referencing it being a report from Rudolph II's court in Prague, Veress (ed.), Documente, vol. 8, 25.

20 Veress (ed.), Documente, vol. 8, 240-241.

21 Tezcan, The Second Ottoman Empire, 141-149.

22 See Ilie Corfus, Documente privitoare la istoria României culese din arhivele polone. Secolul alXVII-lea [Documents regarding the history of Romania, collected from Polish archives. Seventeenth century] (Bucharest, 1983), 33 .

23 Hurmuzaki, Suppl. I/1, 141. 
Ștefan Tomșa II and the influential Tatar aristocrat Kantemir Mirza his sons, and both reciprocated by referring to their Ottoman patron as their father. ${ }^{24}$ This set of alliances yielded fruit in November 1611, when-thanks to Nasuh and Mehmed Pashas' support-Tomșa managed to achieve a victory over his rival Ștefan Bogdan in securing appointment to the Moldavian throne, taking control of the principality the following month. ${ }^{25}$

Thus, by the time he ascended the Moldavian throne for the first time, Stefan Tomșa II was already well-integrated into the political networks of the imperial center through his military service in Anatolia and patronage within grandee households. However, in Moldavia the new voyvode from the beginning faced continuous challenges to his power and staunch opposition coalescing around the Movilă dynasty. In power since 1595, the Movilăs had managed to form a tightly-knit bloc of high-ranking boyar families that held the reins of power and had a vested interest in extending the dynasty's reign: ${ }^{26}$ in contrast, Ștefan Tomșa II, whose career had unfolded beyond Moldavia's confines, had no power base of his own among the boyar elite. Moreover, the Movilăs had pursued a strategy of establishing marital alliances with Polish-Lithuanian magnates of the borderland, who had at their disposal considerable political and military resources that they could invest in a bid to restore their kin to the throne. Seven months into his reign, Tomșa faced an invasion by the Polish magnate Stefan Potocki, Constantin Movilă's brother-in-law, which he managed to repel. However, the opposition continued, and in 1615 a massivealbeit unsuccessful—boyar rebellion broke out. Repression ensued, but the voyvode's unpopularity emboldened the Movilăs to make another bid. ${ }^{27}$ In November, Alexandru Movilă entered Moldavia at the head of an army assembled by his Polish in-laws and managed to oust Tomşa from the principality. As the fighting continued, a power shift in Istanbul removed Öküz Mehmed Pasha, an ally of Tomșa, from power and soon led to the replacement of the voyvode with his Wallachian rival, Radu Mihnea. ${ }^{28}$ Upon Tomșa's return to

24 Korespondencja Krzysztofa księcia Zbaraskiego koniuszego koronnego, 1612-1627 [Correspondence of Prince Krzysztof Zbaraski, the Crown Stablemaster, 1612-1627], ed. Anna Filipczak-Kocur (Opole, 2015), 116.

25 Coulter, "The Involvement of the English Crown," 372-374.

26 Ilona Czamańska, "Rumuńska imigracja polityczna w Polsce XVII wieku" [Romanian political immigration in seventeenth-century Poland], Balcanica Posnaniensia. Acta et Studia 6 (1993): 3-21.

27 Costin, Opere, 62; Ciobanu, Politica și diplomație, 165; Bejenaru, Ștefan Tomșa II, 37-39.

28 Ilona Czamańska, "Kampania mołdawska Samuela Koreckiego 1615-1616 r." [Moldavian campaign of Samuel Korecki in 1615-1616], in Si vis pacem, para bellum: bezpieczeństwo $i$ polityka Polski, ed. Robert Majzner (Częstochowa, 2013), 129-130. 
Istanbul, his possessions were seized by the treasury, although he managed to retain his ties to Ottoman officials, most notably Gürcü Mehmed Pasha. ${ }^{29}$

Tomșa was able to retake the throne in 1621, when growing tensions between Poland-Lithuania and the Sublime Porte erupted into full-scale war and Sultan Osman II personally led a campaign to bring the Commonwealth to its knees. During the campaign, which was marred by difficulties, Gürcü Mehmed Pasha successfully lobbied for Ștefan Tomșa's reappointment to the Moldavian throne, arguing that the latter's military experience would enable him to improve logistics, which had been handled ineptly by the incumbent Alexandru Iliaș. The latter was removed from power and replaced with Tomşa, who benefited from his military credentials and cooperation with his Ottoman patron. ${ }^{30}$

Tomșa's second reign in Moldavia (1621-1623) proved less eventful than the first, and the voyvode seems to have taken steps to sway the local elite. ${ }^{31}$ However, relations with Poland-Lithuania did not improve even after the conclusion of the Polish-Ottoman war. The Commonwealth's diplomats sent to secure an 'ahdname from the Porte repeatedly cited Tomșa's removal as a precondition for lasting peace. In 1622, deteriorating relations sank to new lows and the Polish-Lithuanian ambassador decided to return from Istanbul via Transylvania for fear that Tomșa planned to assassinate him. ${ }^{32}$ The demands were stonewalled at the Porte by Gürcü Mehmed Pasha, determined to protect his client. ${ }^{33}$ However, in March 1623, Mehmed Pasha was removed from the grand vizierate; his successor and adversary, Mere Hüseyin Pasha sought to conclude peace with the Commonwealth and had no interest in protecting Tomșa. In late August 1623, Ștefan Tomșa II was removed from the throne and returned to Istanbul, where he remained until his death.

Factional conflicts and heavy-handed reprisals against the pro-Movilă opposition left an indelible mark on the voyvode's portrayal in historiography. Miron Costin - the only Moldavian chronicler to cover the period under discussion - had family ties to Tomșa's adversaries and a keen interest in solidifying the voyvode's "black legend." Focusing on the harsh reprisals launched

29 Iorga, "Doamna lui Ieremia Vodă" [The Wife of Voyvode Ieremia], Analele Academiei Române. Seria II, 32 (1910): 1068.

$30 \quad$ Bejenaru, Stefan Tomșa II, 82.

31 Dariusz Milewski, "Polskie oczekiwania i polityka wobec obsady tronu mołdawskiego w okresie pochocimskim, 1621-1624" [Polish expectations and policy regarding filling the Moldavian throne after Hotin, 1621-1624], Saeculum Christianum 2o (2013): 99-108; Tahsin Gemil, Țările Române în contextul politic internațional (1621-1672) [Romanian countries in the international political context, 1621-1672] (Bucharest, 1979), 52-53.

32 Kórnik Library, MS 336, f. 17.

33 Milewski, "Polskie oczekiwania," 103-104. 
in the aftermath of the 1615 boyar rebellion, he portrayed the voyvode as an uncouth, brutal, and bloodthirsty tyrant. ${ }^{34}$ As a result, modern historians seeking to rehabilitate Tomșa have focused on military and diplomatic aspects of his reign, while largely ignoring other dimensions of his activity.

However, Ștefan Tomșa II's path to the throne and his relentless mobility provide us with a compelling framework for approaching his self-fashioning strategies, which should be understood within the wider context of the Ottoman Empire. In many respects, the voyvode's career reflected broader trends within the political culture of the empire, characterized by the tumultuous years of celali rebellions and a shift of power towards grandee households. In trying to secure his appointment to the Moldavian throne, he profited from the blurring boundaries between the re'aya and askeri classes and the growing prominence of mercenary troops, playing to his strength as a career soldier. At the same time, he was also able to insert himself into the political networks and the household of Gürcü Mehmed Pasha and to establish numerous ties with key political players at the Porte. While this strategy was successful in securing his appointments to the Moldavian throne, it also had considerable drawbacks. Faced with the entrenched opposition of the boyar elite predominantly aligned with the Movilă dynasty, Ștefan Tomșa failed to secure his own power base in the principality and remained dependent on the support of Ottoman grandees and his own troops to suppress dissent in Moldavia. This failure in many respects defined Ștefan Tomșa II's reign, making him vulnerable to rebellion and accusations of "Turkishness" by his adversaries.

From this point of view, Ștefan Tomșa's political trajectory illustrates a broader trend of growing entanglement and mobility that transcended the boundaries between the "center" and "periphery" of the empire. In the course of the sixteenth century, the Sublime Porte became increasingly involved in matters of succession in its satellite polities, including the Danubian principalities and the Crimean Khanate. While these interventions often took place at the behest of members of local elites seeking to prevail in current struggles for the throne, their cumulative effect changed the parameters of political life and enhanced the role of imperial political networks in the political life of the Porte's tributaries. ${ }^{35}$ As a result, numerous pretenders flocked to Istanbul, in

34 Costin, Opere, 63.

35 On this topic, see Radu G. Păun, "Conquered by the (S)word: Governing the Tributary Principalities of Wallachia and Moldavia (16th-17th Centuries)," in The Ottoman Orient in Renaissance Culture, eds. Robert Born and Michał Dziewulski in collaboration with Kamilla Twardowska (Cracow, 2015), 19-40; Natalia Królikowska, "Sovereignty and Subordination in Crimean-Ottoman Relations (Sixteenth-Eighteenth Centuries)," in The European Tributary State of the Ottoman Empire in the Sixteenth-Seventeenth Centuries, eds. Gábor Kármán and Lovro Kunčević (Leiden, 2013), 58-59. 
the hope that finding an influential patron among Ottoman officials would secure them the throne even if they lacked sufficient local support. ${ }^{36}$ In effect, the interests and priorities upon accession to the throne of individuals such as Ștefan Tomșa II or Sahib Giray I (r. 1532-1551) were more closely aligned with those of their Ottoman patrons than with those of local elites, who frequently opposed their appointment. Moreover, prolonged residence in the imperial capital not only led to their immersion in networks of patronage, but also to their acculturation into the cultural idiom of the imperial elite, making them more likely to integrate Ottoman models into their political activity and self-fashioning strategies. ${ }^{37}$ While hailing from the local elites of the Crimean Khanate and the Danubian principalities, such actors had clear incentives to adapt Ottoman cultural models and to integrate them into their own strategies of self-representation. As I shall argue in the following sections, this embeddedness provides a crucial framework for addressing the image of himself that Ștefan Tomșa II sought to convey to the Moldavian boyars.

\section{Garments: Ştefan Tomşa II and Ottoman Textiles}

Given that Ștefan Tomșa's adversaries in Moldavia cited his preference for Ottoman-style attire as an indelible sign of his "Turkishness," reconstructing the voyvode's sartorial biography would seem a natural step. Unfortunately, in many respects this is a task doomed to fail from the very outset. The evidence regarding the voyvode's wardrobe is limited and any references to specific items of clothing vague. Unlike the case of other members of the Moldavian elite from this period, this dearth of written accounts is not remedied by votive paintings. In effect, the only garments that were certainly in Ștefan Tomșa II's possession are the liturgical vestments he donated to the monastery he established at Solca, which pose considerable interpretative challenges. However, as I shall argue, even the scant evidence helps us in triangulating Tomşa's selffashioning strategy.

36 In 1638, an anonymous informant of Hetman Stanisław Koniecpolski expressed his disgust with Moldavian and Wallachian pretenders, calling them "hunting dogs, who demand appointment" and remarking that "there are scores of those bastards" in Istanbul, Korespondencja Stanistawa Koniecpolskiego, hetmana wielkiego koronnego, 1632-1646 [Correspondence of Stanisław Koniecpolski, the Grand Crown Hetman, 1632-1646], ed. Agnieszka Biedrzycka (Cracow, 2005), 512.

37 See Halil İnalcık, "The Khan and the Tribal Aristocracy: The Crimean Khanate under Sahib Giray I," Harvard Ukrainian Studies 3-4, no. 1 (1979): 458-46o; Natalia Królikowska-Jedlińska, Law and Division of Power in the Crimean Khanate (1532-1774): With Special Reference to the Reign of Murad Giray (1678-1683) (Leiden, 2018), 53-54. 
Only two accounts provide us with any reference to individual garments in the voyvode's possession. In a report from August 1616, Dutch ambassador Cornelius Haga states that upon Tomșa's arrival in Istanbul he received a brocade kaftan (veste van broccado) from his patron, Gürcü Mehmed Pasha. ${ }^{38}$ This gift came at a particularly critical moment in Tomșa's career when, following his removal from the throne, he faced the confiscation of his property by the Ottoman authorities. In this context, receiving the robe from Mehmed Pasha acquired political importance, demonstrating the grandee's continued interest in supporting his Moldavian client, even if the latter was temporarily ousted from power.

Another author who refers to Ștefan Tomșa's garments is Samuel Twardowski, a Polish nobleman and poet, who in 1622 accompanied his patron, Prince Krzysztof Zbaraski, on a diplomatic mission to the Porte, and composed an epic poem eulogizing the embassy. ${ }^{39}$ In his rendition, the Moldavian voyvode welcomes the magnate dressed in a lavish golden kaftan. Several verses later, he provides another description of the garment, pointing out that Moldavians tend to don heavy robes even when the weather is nice and warm. ${ }^{40}$ The garment described by Twardowski was clearly a kaftan made of serâser (cloth-ofgold), a costly and prestigious fabric closely associated with courtly life. ${ }^{41}$ Given its prestige, serâser kaftans were much sought after by Ottoman elites, Muslim and Christian alike. ${ }^{42}$ As such, they featured prominently as gifts distributed by the sultan and exchanged between members of the imperial elite. ${ }^{43}$ Moreover, as sources of the period suggest, donning a cloth-of-gold garment at the reception of a high-ranking guest was seen as a sign of favor among Orthodox subjects of the empire. ${ }^{44}$ However, in this particular case, Tomșa's goal was not

38 Nicolae Iorga, "Doamna lui Ieremia Vodă," 1036.

39 Samuel ze Skrzypny Twardowski, Przeważna legacyja Krzysztofa Zbaraskiego od Zygmunta III do sottana Mustafy [The All-Famous Embassy of Krzysztof Zbaraski from Sigismund III to Sultan Mustafa], ed. Roman Krzywy (Warsaw, 200o), 63.

40 Twardowski, Przeważna legacyja, 64.

41 It is important to note that in the seventeenth century we encounter various grades of serâser, see Amanda Phillips, "Ottoman Hil'at: Between Commodity and Charisma," in Frontiers of the Ottoman Imagination: Studies in Honour of Rhoads Murphey, ed. Marios Hadjianastasis (Leiden, 2015), 132.

42 Nikolaos Vryzidis, "Towards a History of the Greek Hil'at: An Interweaving of Byzantine and Ottoman Traditions," Convivium 4, no. 2 (2017): 182-185.

43 On this topic, see Hedda Reindl-Kiel, "Breads for the Followers, Silver Vessels for the Lord: The System of Distribution and Redistribution in the Ottoman Empire (16th-18th Centuries)," Osmanlı Araştırmaları 42 (2013): 101.

44 T. Kaplanis, Ioakeim Kyprios' Struggle: A Narrative Poem on the 'Cretan War' of 1645-1669 (Nicosia, 2012), 130; Nikolaos Vryzidis, "Ottoman Textiles and Greek Clerical Vestments: 
to honor the Polish-Lithuanian ambassador, but rather to engage in a competition of splendor with Zbaraski, whose massive entourage numbered over a thousand men. ${ }^{45}$

Unfortunately, both Haga's and Twardowski's descriptions are too vague to enable any definite conclusions. However, on their basis it is hard to see why Tomșa's sartorial choices would set him apart from his predecessors on the throne or from the boyar class in general. While the items of clothing mentioned by both authors were clearly of Ottoman origin, they conform to general trends among Moldavian elite and Orthodox Christian notables throughout the empire. For instance, a 1594 inventory of goods belonging to Ștefan, son of former voyvode Peter the Lame, lists two serâser kaftans. ${ }^{46}$ Likewise, votive paintings from this period portray Tomșa's contemporaries in garments similar to those described above. Thus, while the voyvode's garments can be interpreted as conveying "the social message of an alignment with the Ottoman court aesthetic,"47 this was part of a general trend among Moldavian-and Ottoman-Orthodox-elites, and there is no indication that Ștefan Tomșa II stood out in this respect.

The surviving textiles attributable to Ștefan Tomșa II —liturgical garments donated to Solca monastery - seem to point in the same direction. The monastery was established during his first reign in Moldavia and was intended both as an expression of his piety and as a future burial place..$^{48} \mathrm{In}$ line with these aims, the foundation quickly became a major recipient of both extensive landed estates (thirty villages and parts of villages by 1623), and liturgical objects commissioned by the voyvode. ${ }^{49}$ However, the region's tumultuous history did not spare the monastery, which was repeatedly plundered in the following century and in 1785 closed down by the Habsburg authorities, who had taken control of Bukovina a decade earlier; objects that constituted part of Tomșa's endowment were subsequently scattered among institutions in the region and beyond.

In her meticulous study, Maria Magdalena Székely manages to identify objects that belonged to the voyvode's original endowment and to match them

Prolegomena on a Neglected Aspect of Ecclesiastical Material Culture," Byzantine and Modern Greek Studies 42, no. 1 (2018): 98.

45 For Zbaraski's reception in Moldavia, see Michał Wasiucionek, "Diplomacy, Power and Ceremonial Entry: Polish - Lithuanian Grand Embassies in Moldavia in the Seventeenth Century," Acta Poloniae Historica 105 (2012): 71.

46 Hurmuzaki, vol. 3, 90-91.

47 Vryzidis, "Ottoman Textiles," 100.

48 On the monastery, see Erast Costea, Ctitoria voievodului Ștefan Tomșa al II-lea de la Solca (1613-1785-1838) [Voyvode Ștefan Tomșa II's endowment in Solca, 1613-1785-1838] (Chernivtsy, 1939).

49 Iacob, Tara Moldovei, 297-305. 
with an eighteenth-century inventory of the monastery's property. ${ }^{50}$ While the sample-which includes five liturgical vestments together with two fragments, a dveră (altar curtain), and an icon cover - is relatively small and its ecclesiastical purpose poses interpretative challenges, it nonetheless provides us with the best opportunity to probe Ștefan Tomșa II's sartorial tastes.

Stylistically, the vestments fall into two categories, encountered also in other collections from Orthodox sacristies in the Ottoman Empire. Two phelonia feature a repertoire typical of Ottoman silks designed for ecclesiastical use, namely a repetitive pattern representing Christ as a High Priest, placed within roundels. ${ }^{51}$ The presence of Christian iconography indicates that they were conceived and produced for ecclesiastical consumption. Two other pieces, on the other hand - a phelonion and a sticharion, currently in Sucevița Monastery-represent a second category, decorated with large aniconic motifs, most notably tulips, pomegranates, and carnations (see Figure 1).

That Ștefan Tomșa considered the vestments donated to Solca prestigious and precious objects is suggested by the fact that each of the garments contains an embroidered inscription around the collar, commemorating the donation and stating its purpose as redeeming the voyvode's "soul, those of his parents and of his children."52 Given the solemnity of the inscriptions and Solca's role as the main recipient of Tomșa's patronage, it seems plausible that he took considerable care in choosing objects he considered deserving for his future place of burial. ${ }^{53} \mathrm{~A}$ comparison with other collections of textiles shows that the vestments conformed to the dominant aesthetic of Ottoman textiles, which enjoyed popularity and prestige among Orthodox elites. ${ }^{54}$ This prestige was further demonstrated by the inclusion of such garments in church wall paintings. 55

50 Maria Magdalena Székely, "Pe urmele vechilor odoare ale Mănăstirii Solca" [Tracing adornments of the Solca Monastery], Analele Putnei 15, no. 1 (2015): 287-320; Suceava, Romanian National Archives—Suceava Branch, M-rea Putna ii $/ 19$.

$5^{1} \quad$ Vryzidis, "Ottoman Textiles," 106-107.

52 Székely, "Pe urmele," 291-292.

53 It is possible that vestments with aniconic motifs-all of which were reused from different garments - were originally kaftans used by the donor, which was a standard practice, see Nicolescu, Istoria costumului, 17. However, the nature of changes makes it difficult to reconstruct original garments, see Vryzidis, "Towards a History," 182.

54 Vryzidis, "Ottoman Textiles," 99.

55 Verena Han, "Les courants des styles dans les métiers d'art des artisans chrétiens au XVI siècle et durant les premieres decennies du XVII ${ }^{\mathrm{e}}$ siècle dans les regions centrales des Balkans," Balcanica 1 (1970): 25 o. 


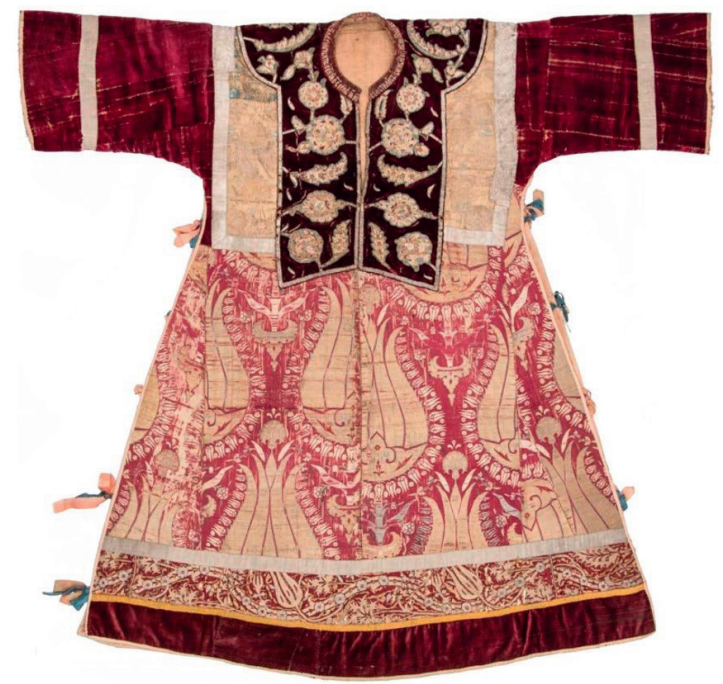

FIGURE 1

Sticharion donated by Ștefan Tomșa II to Solca Monastery in 1614 (Sucevița Monastery) SZÉKELY, “PE URMELE VECHILOR ODOARE,” 309.

Taken together, the evidence of Tomșa's garments is hardly overwhelming if we compare it with the tone adopted by his detractors. While he indeed embraced Ottoman sartorial culture, his choice of attire did not diverge significantly from the aesthetic and material parameters of the Orthodox elites in Moldavia and across the empire. Given the paucity and character of the sources, we should not rule out the possibility that Tomşa conveyed his "Ottomanness" through more nuanced means; the overall impression, however, is that if so, these were not significant enough to register in contemporary accounts. It seems that the voyvode's "Turkish" garments were not so much an issue due to their Ottoman style but were instead politicized to discredit him. Why this should be the case would be impossible to understand without taking into consideration his political alliances at the Porte.

While this conclusion would suggest that the accusations of the voyvode's "Ottomanness" were mere slander, a clue that Ștefan Tomșa diverged from his contemporaries in emphasizing his association with the Sublime Porte is provided by a very different piece of fabric. In 1622, Prince Krzysztof Zbaraski arrived in Iaşi en route to Istanbul. As I have mentioned earlier, tensions between the ambassador and the Moldavian voyvode were running high, and the customary ceremonial entry into the city was marred by squabbles over precedence. In his elaborate description of the welcome party and the respects paid to his patron by the hosts, Samuel Twardowski notes that the welcome party led by the voyvode hoisted two banners: the first was green and sported an Ottoman crescent, while the other represented Moldavia, with an aurochs head set against a red background. In a marginal note, the poet clarifies that 
"the Moldavian voyvode receives the banner from the sultan as a vassal. The other is that of the land." 56

At first glance, the presence of an Ottoman banner seems unsurprising given that the voyvode's position as a tributary of the Porte was not contested. However, once we set this detail against the background of other Polish-Lithuanian embassies visiting Iași in this period, it becomes clear that this was by no means a standard practice. No other ambassadorial report from this period refers to the banner's presence during the ceremonies. In 1677 , Voyvode Antonie Ruset explicitly rejected the ambassador's demand that he fly Ottoman colors, arguing that he had been banned from doing so by the Porte. ${ }^{57}$ Given the abysmal relations between Poland-Lithuania and Tomșa at the moment of Zbaraski's mission, it would come as no surprise that the voyvode-enjoying the support of his patron, Gürcü Mehmed Pasha—would choose to remind the envoy of his ties at the Porte and backing he received from Istanbul.

Obviously, this by no means proves that the voyvode presented himself as a member of the Ottoman elite. While the garments associated with Tomşa were Ottoman in style and origin, they reflected a more comprehensive sartorial culture among the Orthodox elites of his time. Similarly, hoisting an Ottoman banner can be explained in terms of political alignment between the voyvode and the Porte. However, another set of sources-Moldavian chancery documents-suggest that Tomşa indeed employed a self-fashioning strategy that cast him as a member of the imperial elite.

\section{Signing Identity: Moldavian Diplomatics and Fashioning Ottoman Identity}

A major obstacle in the way of approaching seventeenth-century Moldavian identities is the dearth of extant ego-documents produced by the local elite. This can be only partially compensated for by mining the extant historical narratives, parenetic literature produced by members of the boyar class or accounts penned by foreigners residing in the Danubian principalities. However, by far the most numerous type of internal sources are the documents issued by the voyvodal chancery with regard to boyars' landed property.

$56 \quad$ Twardowski, Przeważna legacyja, 64.

57 Źródta do poselstwa Jana Gnińskiego, wojewody chetmińskiego do Turcyi w latach 1677-1678 [Sources on the embassy of Jan Gniński, the Palatine of Kulm, to Turkey, 1677-1678], ed. Franciszek Pułaski (Warsaw, 1907), 10. 
However, how can we approach such sources in search of someone's identity and strategies of self-representation? After all, in many respects, the chancery documents may seem like the opposite of ego-documents, due to their official and formulaic character, which follows chancery traditions. Moreover, since they were penned by clerks rather than by the voyvode himself, the question of authorship also poses another valid argument against approaching them as any form of surrogate ego-documents. On the other hand, the sheer number of extant chancery documents when compared with other types of Moldavian sources provides us with a rare glimpse into the realities of the seventeenth century and makes their analysis a necessary part of any research.

To reconcile methodological reservations and the accessibility of the sources produced by the Moldavian chancery, scholars have focused on the rhetorical aspect of the documents, tracing subtle shifts in their wording. In the case of Ștefan Tomșa II's reign, we can identify certain shifts within the rhetoric employed in the documents penned by the voyvodal scribes. Most important in this respect is the framing of boyars' rebellious acts against the voyvode, described in Moldavian practice as either hiclenie or hainie. While both terms described rebellion, there were nonetheless subtle differences in their application. Hiclenie, an older term, carried religious connotations and indicated the breaking of an oath. ${ }^{58}$ The concept of hainie, on the other hand, originating in Ottoman Turkish, entered Romanian vocabulary at a later date, and its usage was far more precise, indicating rebellion against the Ottoman sultan. In the documents issued by the voyvode, we may observe that they convey the latter notion, framing boyars' attempts to oust him from the throne as an act of rebellion "against my rule and the scepter of the virtuous emperor."59

While this shift in emphasis is subtle, it is also indicative of the way Ștefan Tomșa II legitimated his reign in Moldavia. Despite the fact that the principality had firmly entered the Ottoman orbit in the sixteenth century, the documents issued by the chancery continued to maintain that voyvodal authority was autocratic and God-given. Through this fiction, the realities of the rulers' subordination to the sultan remained unchallenged and were simply ignored within the internal discourse of legitimacy. In this context, Tomșa's inclusion of the sultan as the source of voyvodal authority should be understood as a deliberate effort to intimidate the opposition by framing his power as delegated by the Ottoman sultan and enjoying the Porte's support.

$5^{8}$ Alexandra-Marcela Popescu, "Hiclenia - explicații terminologice" [Hiclenia - terminological explications] Cercetări Istorice 32 (2013): 168.

59 Documenta Romaniae Historica. Seria A. Moldova, vol. 17, ed. Ion Caproșu and Valentin Constantinov (Bucharest, 2006), 87. 


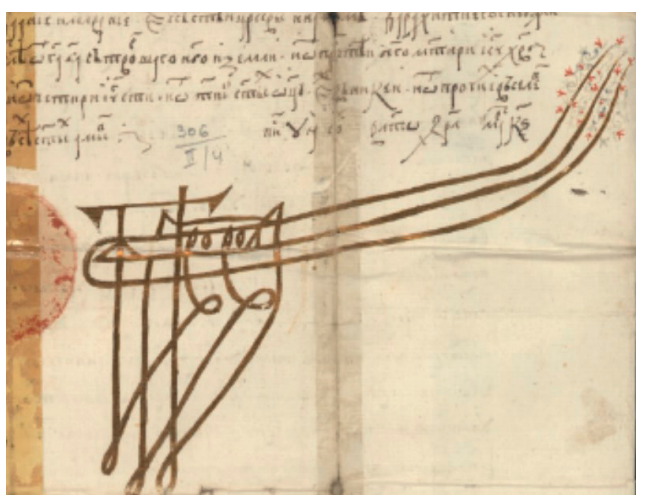

FIGURE 2

Ștefan Tomșa II's pseudo-tuğra SJAN-Iaşi, M-rea Galata ii/4 PHOTO BY MIHAI MîRZA.

However, the most fascinating evidence of Ștefan Tomșa II's self-fashioning strategy comes not from the contents of the documents, but from their appearance. By the beginning of the seventeenth century, the Moldavian chancery tradition had largely reached its maturity in terms of document structure and format, and also in forms of authentication. These included a wax seal applied below the body of the document and-increasingly — the signature of the voyvode or the Grand Logofăt (chancellor). In this respect, the documents issued during the reign of Ștefan Tomșa do not diverge from established practice, all the standard features being present and identifiable. What distinguishes them is the unique calligraphic arrangement of the voyvodal signature, which constitutes a striking departure from other Moldavian ciphers and bears an even more striking resemblance to the tuğras of Ottoman sultans and Crimean khans (see Figure 2). ${ }^{60}$

A closer examination shows that despite similarities with Ottoman and Crimean models, there are significant differences as well. Firstly, the signature is written in Cyrillic script, the text reading Stefan voevoda in a heavily abbreviated form. Moreover, in comparison with the tugras of sultans and khans, the symbol is inverted with three tuğs facing downwards rather than upwards. Finally, the placement of the cipher below the text conforms to Moldavian usage rather than Ottoman-Crimean format, in which the sultanic monogram is placed at the top of the document, just below the invocatio. Nonetheless, the Ottoman inspiration behind the signature's design is clear.

Given the limited space of the present study, it is impossible to engage here in an in-depth analysis of this fascinating sign and the way it came to be

6o Iași, Romanian National Archives—Iași Branch (hereafter SJAN-Iași), M-rea Galata ii/4. On the Ottoman tuğras, see Suha Umur, Osmanlı Padișah Tuğraları [Tuğras of Ottoman Sultans] (Istanbul, 1980). 
used in Moldavian chancery documents. ${ }^{61}$ However, the structural features of Ștefan Tomșa II's monogram suggest that the visual resemblance to Ottoman and Crimean models was deliberate. The voyvodal pseudo-tuğra seems to constitute a hybrid sign, deliberately crafted to fuse recognizably Ottoman models and the Moldavian calligraphic tradition and to be a key element in the selffashioning strategy pursued by Ștefan Tomșa II, with the aim of emphasizing his connection to the Ottoman imperial center.

That we should understand the pseudo-tuğra as a politically meaningful act rather than simple stylistic choice is suggested by the complex process in which the sultanic model was transformed and adapted for local needs. The crucial differences between the Arabic and Cyrillic scripts meant that this transition posed a considerable challenge, most importantly with regard to the direction of the text as well as the radically different shape of individual letters. Nonetheless, we may observe a concerted effort to overcome these obstacles, which explains the divergences from the Ottoman model. Most importantly, it seems that the decision to invert the tuğra's shape along the horizontal axis can be explained by the need to accommodate the fact that Cyrillic script—unlike Arabic script—runs from left to right. As a result, the three upward facing tuğs of the sultanic cipher face downward in the Moldavian rendition, containing the stems of the $T, F$, and $N$ of the voyvode's name, while the letter $S$ forms a small loop, greatly reduced in comparison with the Ottoman model.

Despite these efforts, the relative inflexibility of Cyrillic script meant that not all elements of the voyvode's name and title could be accommodated without obscuring the visual resemblance to the Ottoman model. The tradeoff tilted in favor of the visual aspect of the monogram: not only is the voyvode's name heavily abbreviated, but also crucial elements are absent from the ruler's title. A symbolic invocation in the form of the cross is missing, as is the Io formula preceding the ruler's name. ${ }^{62}$ Since both had been deeply ingrained in Moldavian chancery practice and constituted potent symbols of voyvodal legitimacy, their absence indicates that the visual resemblance to a tuğra was

61 I am currently preparing a detailed paleographic study of the symbol.

62 Among over thirty documents bearing Tomşa II's pseudo-tuğra, only one (sJAN-Iași, M-rea Bisericani iv/5) includes the symbolic invocation. See Damian P. Bogdan, "Diplomatica slavo-romînă" [Slavonic-Romanian diplomatics], in Documente privind istoria României, vol. 2 (Bucharest, 1956), 76. On the Io/Ioan in chancery practice, Emil Vârtosu, Titulatura domnilor și asocierea la domnie în Țara Românească și Moldova (secolul al XVI-lea) [Titles of voyvodes and association to the throne in Wallachia and Moldavia, sixteenth century] (Bucharest, 1960), 183-196; Andrei Pippidi, Tradiția politică bizantină în Țările Române în secolele XVI-XVIII [Byzantine political tradition in Romanian countries in sixteentheighteenth centuries], 2nd ed. (Bucharest, 2001), 25-29. 
a top priority. This preference for form over content is a clear indication that Ștefan Tomșa II intended his monogram to provide a clear visual reference to the Ottoman blueprint and was ready to sacrifice important elements of the local tradition in the process.

These choices acquire new meaning when we take into consideration the cipher's intended audience. Documents bearing the pseudo-tuğra were issued by the voyvodal chancery to members of the Moldavian boyar elite, who were predominantly resentful towards Ștefan Tomșa II and supported his Movilă rivals. After all, it is from this socio-political milieu that the accusations of the voyvode's "Turkishness" originated even before he took power in December 1611. That the unpopular voyvode decided to authenticate his documents with this Ottoman-inspired cipher shows that his response to these accusations was not to deny the association, but rather to embrace it in his self-fashioning strategy, which he continued until his second deposition in 1623. Thus, the hybrid, Ottoman-Moldavian character of the pseudo-tuğra constituted a visual expression of the image the voyvode intended to convey, as both the local ruler and a representative of the Ottoman imperial center. Given the low level of literacy among the Moldavian elite and the intricate arrangement of the monogram, one could even argue that the visual reference to the sultanic tuğra was more legible than its Moldavian-style content.

Placing Ştefan Tomşa II's monogram within the wider context of seventeenth-century Ottoman society and its graphic conventions, we are able to observe some striking parallels. Since at least the times of Orhan, the tuğra had been one of the most important symbols of Ottoman dynastic authority, appearing on documents, coins, and seals. This function as an index of sultanic authority and its practical application as means of authenticating coins and documents meant that although it enjoyed wide circulation across the "wellprotected domains," its legitimate usage was restricted to those authorized by the ruler. Usurping the symbol was considered a direct ideological challenge and act of open rebellion. ${ }^{63}$

However, starting from the sixteenth century, we witness the proliferation of signatures and other calligraphic arrangements modeled after the sultanic monogram. The familiar shape of a tuğra was increasingly adopted by individuals from outside the dynastic circle in their own signatures, as well as for other purposes. As a result, we find what I would call tuğra derivates in a variety of new contexts, such as invocations (da'vet) opening fetvas, personal

63 Mustafa Selâniki, Tarih-i Selâniki (1003-1008/1595-1600), vol. 1, ed. Mehmed İpşirli (Istanbul, 1989), 837 . 
documents, and even on objects of everyday use. ${ }^{64}$ Even existing conventions of signing documents, such as "tail-signatures" (kuyuklu imza), increasingly adopted features originating from the sultanic monogram. ${ }^{65}$ At the same time, the use of the sultanic tugrra also extended into new spheres of artistic production, where it had rarely been employed. Beyond the sphere of calligraphic conventions, tuğras became a popular topos in Ottoman poetry. ${ }^{66}$ These changes culminated during the reign of Ahmed III (r. 1703-1730) when the imperial elite became engulfed in what Philippe Keskiner has recently dubbed a veritable "tuğra-mania."67

Arguably the most interesting case of this trend is the emergence of Crimean tuğras, which exhibit considerable similarities with Ştefan Tomşa II's case. In a similar manner to Moldavia, the Crimean Khanate had its own chancery tradition, originating from the models employed by the Golden Horde. This also applied to the way the Giray khans' chancery authenticated documents. As Sagit Faizov and Dariusz Kołodziejczyk have shown, the corroboration took three forms: impressing a tamga/nișan seal on the document, attaching a round hanging seal (baysa) to the document, and the sözümüz formula, proclaiming the document to be the khan's word. ${ }^{68}$ For the purpose of this study, the most interesting is this last form of corroboration and the visual and textual evolution of the formula. As the preserved documents show, by the beginning of the sixteenth century, the formula was elaborate in terms of the rhetoric and titles employed but did not distinguish itself visually, constituting the first line of a document's main body. However, in the second half of the sixteenth century, this balance was gradually reversed, with the formula becoming shorter and at the same time increasingly separated from the main text and stylized. At the beginning of the seventeenth century, this process was complete, with the sözümüz formula coalescing into an identifiable tuğra. ${ }^{69}$

64 For instance, Uriel Heyd, "Some Aspects of the Ottoman Fetvā," Bulletin of the School of Oriental and African Studies 32, no. 1 (1969): 38.

65 Maria Pia Pedani, "Le prime 'sottoscrizoni a coda' dei tesorieri nell'Impero ottomano," Quaderni di Studi Arabi 8 (1990): 223-227.

66 Ahmet Mermer, "Divan şiirinde tuğra tavsifleri" [Descriptions of tuğras in divan poetry], Bilig 14 (2000): 87-96.

67 Philippe Bora Keskiner, "Sultan Ahmed III (r. 1703-1730) as a Calligrapher and Patron of Calligraphy," (Ph.D. diss., School of Oriental and African Studies, 2012), 246.

68 Dariusz Kołodziejczyk, The Crimean Khanate and Poland-Lithuania: International Diplomacy on the European Periphery (15th-18th Century) (Leiden, 2011), 321-364; Sagit Faizov, Tugra $i$ Vselennaya. Mokhabbat-name i shert-name krymskikh khanov i printsev $v$ ornamental'nom, sakral'nom i diplomaticheskom kontekstakh [Tuğra and Universe: Mohabbat-name and şert-name of Crimean khans and princes in ornamental, sacral and diplomatic contexts] (Moscow, 2002).

69 Kołodziejczyk, The Crimean Khanate, 345-346. 
Stylistic similarities and chronological overlap between Ştefan Tomşa II's adoption of his pseudo-tuğra and the maturation of Crimean monograms suggests that we should see both as hypostases of a wider trend on an imperial scale rather than just artistic choices of scribes in Bahçesarayı and Iași. While further research is needed, it seems plausible that the growing role of the tuğra within the wider Ottoman semiosphere originates from the social and political changes of the period. Starting from the second half of the sixteenth century, the Ottoman polity and society were undergoing major changes, which resulted in the emergence of what Baki Tezcan has aptly labelled "the Second Ottoman Empire."70 One of the central features of this new model was the emergence of a more inclusive political sphere, which encompassed ever-growing sections of society. The extension of imperial networks both vertically-down the social hierarchy — and horizontally —into the provinces—-led peripheral elites increasingly to identify themselves with the imperial center and to adopt Ottoman self-fashioning strategies. ${ }^{71}$ This, in turn, would naturally lead these newly-integrated groups to search for novel forms and symbols capable of expressing their association with the empire. As the most widespread and recognizable symbol of dynastic authority, the tuğra offered an ideal blueprint, which could be assimilated and adapted to serve precisely this purpose. ${ }^{72}$ Thus, the wave of tuğra derivates and "tuğra-mania" of the later period can be interpreted as a calligraphic expression of the emerging Ottoman identity.

Against this background, it seems justified to argue that the appearance of Ştefan Tomşa II's pseudo-tuğra is by no means an isolated episode, but rather a reflection of an empire-wide social and cultural trend, although ultimately shaped by local conditions. Facing the opposition of entrenched Movilă supporters, who attacked him for his association with the Ottoman center, Ștefan Tomșa II responded with a self-fashioning strategy that embraced rather than denied the connection in order to consolidate his rule, a strategy clearly discernible in his tuğra-shaped monogram.

However, Tomşa's enemies eventually prevailed, succeeding not only in removing him from the throne, but also in painting his "black legend" in historiography. Given Tomşa's widespread unpopularity, his successors on the Moldavian throne were eager to dissociate themselves from him, which included cutting short his pseudo-tuğra experiment and a return to a more conventional form of monograms. However, it would be a mistake to consider

\footnotetext{
70 Tezcan, The Second Ottoman Empire, 18-19.

71 Ibid., 11.

72 For a similar phenomenon among Orthodox bishops, see Nicolas Oikonomides, "Réflexions sur le monocondyle episcopal du $16^{\mathrm{e}}$ siècle," in I elleniki graphi kata tous $15^{\mathrm{O}}$ kai $16^{\circ}$ aiones, ed. Sophia Patoura (Athens, 2000), 53-63.
} 
this a form of general de-Ottomanization. After all, Tomşa's main rival and immediate successor, Radu Mihnea, was more than eager to embrace Ottoman material culture and he kept his Muslim half-brothers at the court. Even the tuğra-shaped signature did not disappear completely, as we find the same model employed by Tomşa's descendants, Wallachian voyvodes Leon Tomşa (1629-1632) and Radu Leon (1664-1668). ${ }^{73}$

\section{Conclusion}

Throughout the present study, the overarching goal has been to recover Ştefan Tomşa II's self-fashioning strategy within broader Moldavian and Ottoman contexts. As I have mentioned, this has proven a complex task, particularly with regard to the voyvode's sartorial choices, singled out by his adversaries as a marker of "Turkishness." Despite the centrality of such claims, the scarce evidence suggests that there was nothing extraordinary in Tomşa's choice of garments, which conformed to general trends among the Orthodox elites of the empire. In this context, it would be easy to dismiss the accusations of the voyvode being a "Turk" as mere political slander by his opponents. However, as I have pointed out, merely dismissing the allegations would miss the mark. While analyzing Tomşa's garments fails to yield evidence of his "Ottomanness," it is confirmed by a different set of sources, namely the documents issued in his name. It is only by retracing various facets and circuits of Ştefan Tomşa II's activity that we can trace the ways in which people, objects, and ideas circulated between Istanbul and Moldavia, and draw some wider hypotheses regarding the complex process of integration of the early modern Ottoman Empire.

Firstly, the three types of circulation - of people, objects, and ideas-should be understood as entangled circuits rather than distinct phenomena. Since objects and ideas did not travel on their own, they depended on the movement of individuals and their agendas. Hence, the process of Ottomanization was not a homogenous, disembodied diffusion of imperial models, but a product of cumulative actions of actors pursuing their own goals. The result was not a uniform diffusion of imperial models, but a negotiated phenomenon that progressed by fits and starts, producing what Marc Aymes has aptly labelled different "hues of Ottomanness."74

73 For Leon Tomșa see, Bucharest, Romanian Academy Library (BAR), Documente istorice lxviii/18. For Radu Leon, BAR, Documente istorice c/168.

74 Marc Aymes, A Provincial History of the Ottoman Empire: Cyprus and the Eastern Mediterranean in the Nineteenth Century (London, 2013), 126. 
Secondly, the incorporation of Ottoman self-fashioning tools by the Moldavian voyvode demonstrates the potential the Danubian principalities have for addressing broader topics throughout the empire. While Moldavia and Wallachia have been on the margins of Ottomanist historiography, political trajectories such as that of Ştefan Tomşa II's demonstrate that they were politically, socially, and culturally embedded in the imperial fabric. Integrating this oft-ignored periphery into more traditionally "Ottomanist" topics offers fresh insight into such issues as Ottomanization, self-fashioning, and political patronage, allowing students of the empire to shed new light on the phenomena.

Thirdly, by combining different strands of scholarship and wildly diverse sources, the study has aimed to show the possibilities of remedying one of the more pervasive limitations in Ottoman and Romanian historiographies, namely the dearth of ego-documents and self-narratives. The relative dearth of such accounts and the reliance on diplomatic correspondence, chronicles, and official documents make it extremely difficult to sketch even the most approximate portraits of individual members of Moldo-Wallachian and Ottoman elites alike. The effect is that too often we have nothing more than a name with a cursus honorum and a list of known associates attached. Even the most mundane and seemingly unconnected sets of material and documentary sources can provide us with unexpected insights and help us at least partially to recover the voice of individuals who would otherwise remain silent. In the case of Ștefan Tomșa II, modern scholars have interpreted the allegation that he was effectively a Turk as political slander. However, as this study has shown, this is precisely how he wanted to be seen.

\section{Acknowledgements}

This research project has been supported by funding from the European Research Council (ERC) within the project Luxury, Fashion and Social Status in Early Modern South-Eastern Europe (LuxFaSS, grant ERC-2014-CoG 646489), hosted by New Europe College in Bucharest. I would like to thank Constanța Vintilă-Ghițulescu, Mária Pakucs, Nicoleta Roman, Liviu Pilat, Giulia Calvi, Dariusz Kołodziejczyk, Silvana Rachieru, Hedda Reindl-Kiel, Giancarlo Casale, Mihai Mîrza, Silviu Văcaru and anonymous JEMH reviewers for their help and insightful comments on the essay. 